\title{
IN VITRO ANTIOXIDANT CAPACITY, PHENOLIC, ASCORBIC ACID AND LYCOPENE CONTENT OF GUAVA (Psidium guajava L.) JUICES AND NECTARS
}

\author{
CARLOS ALEXANDRE KOGUISHI DE BRITO* \\ PRISCILA BECKER SIQUEIRA** \\ JANE CRISTINA DE SOUZA*** \\ HELENA MARIAANDRÉ BOLINI ${ }^{\star \star \star \star ~}$
}

\begin{abstract}
The aim of this work was to determine the antioxidant capacity in vitro of three different brands of guava nectars and juices, through free radicals scavenging methods, 1,1diphenyl-2-picrylhydrazine (DPPH) and 2,2'-azino-bis(3ethylbenzthiazoline-6-sulphonic acid (ABTS ${ }^{+}$), and its correlation with the total polyphenolic content, total lycopene and ascorbic acid. Brands revealed statistical differences $(p \leq 0.05)$ in antioxidant capacity, ranging from 1.9 to 7.7 molTE/mL. Antioxidant capacity presented positive correlation for ascorbic acid content and polyphenolic compounds, being relatively low for the lycopene. Different process can influence the content of these compounds as well as interfere in their antioxidant capacity. The control of the production process is important to add value to guava products and fulfill the new tendency of the market.
\end{abstract}

* Mestre em Ciência de Alimentos, Departamento de Alimentos e Nutrição, Faculdade de Engenharia de Alimentos, (FEA) Universidade Estadual de Campinas (UNICAMP), Campinas, SP, Brasil (e-mail: cako.brito@gmail.com).

** Mestre em Ciência de Alimentos, Departamento de Ciência de Alimentos, FEA, UNICAMP, Campinas, SP, Brasil (e-mail:pribecker@gmail.com).

*** Mestre em Alimentos e Nutrição, Departamento de Alimentos e Nutrição, FEA, UNICAMP, Campinas, SP, Brasil (e-mail:janenutri@gmail.com).

*** Professora, Departamento de Alimentos e Nutrição, FEA, UNICAMP, Campinas, SP, Brasil (email:hellini@fea.unicamp.br). 


\section{INTRODUCTION}

Brazil is one of the richest countries in tropical fruits, among them guava (Psidium guajava L.), a flavored and perfumed fruit (PORCU,2004). It's considered a highly nutritious fruit because it contains a high level of ascorbic acid, and red-fleshed Brazilian guava has several carotenoids such as $\beta$-carotene, rubixanthin, lutein, cryptoflavin, phytofluene and lycopene (MERCADANTE, 1999).

The frequent consumption of natural antioxidants particularly in fruits and vegetables is associated to lower risk of degenerative diseases such as cancer, arthritis, arteriosclerosis, cardiovascular and acceleration of the ageing process. Antioxidants are substances that can prevent or delay oxidative damage of lipids, proteins and nucleic acids by reactive oxygen species which include free radicals and non-radicals. Three major groups: vitamins, phenolics and carotenoids are related to the defensive effects of natural antioxidant in fruit. They are separated in two groups: hydrophilic antioxidant (ascorbic acid and phenolics) and lipophilic antioxidant (carotenoids) (ARNAO, CANO \& ACOSTA, 2001). The antioxidant properties of a number of tropical fruits have been investigated and several assays have been frequently used to estimate antioxidant capacities in fresh fruits and their products, including 2,2-azinobis (3-ethyl-benzthiazoline-6-sulfonic acid) (ABTS-) and 2,2-diphenyl-1 picrylhydrazyl (DPPH) (THAIPONG et al., 2006). Both models are recommended as useful tools for evaluating the total antioxidant capacity of fruits (LEONG \& SHUI, 2002). These natural pigments in fruits, such as carotenoids, are fairly stable in their natural environment in intact cells, but they can become much more labile when fruits are subjected to postharvest treatments or processing (FORGET, GAUILLARD \& RIGAL,2000).

The aim of this research was to compare the efficiency of ABTS ${ }^{+}$and DPPH assays to estimate in vitro antioxidant capacities and their correlations with ascorbic acid, total phenolics and total lycopene contents in commercial guava juices and nectars proceeding from different States of Brazil.

\section{MATERIAL AND METHODS}

\subsection{SAMPLES}

Six samples of processed guava juices and nectars of three different brands proceeding from States of Southeast and Northeast of Brazil and commercialized in the city of Campinas-SP were used.

\subsection{DETERMINATION OF TOTAL CAROTENOID (TOTAL LYCOPENE CONTENT)}

Each sample was prepared from a mixture of 3 liters of guava juice and nectar from each commercial brand with the same lot of manufacture. From each sample, $5 \mathrm{mg}$ was separated in duplicate for determination of total carotenoids.

\subsubsection{Extraction of lycopene with acetone using a mortar and pestle}

This methodology was based on Screening Method of RODRIGUEZ-AMAYA (1999), in which a portion (about $5 \mathrm{~g}$ of guava juice or nectar) was weighted and transferred to a mortar and a small amount ( $3 \mathrm{~g}$ ) of Hyflosupercel (celite) was added. This mixture was grinded with $50 \mathrm{~mL}$ of cold acetone (acetone refrigerated for about 2 hours) and filtered with suction through a Buchner funnel with filter paper.

\subsubsection{Partition to petroleum ether}

The extract was transferred to separatory funnel with $50 \mathrm{~mL}$ of petroleum ether (PE) and portions of methanol were added. Distilled water $(\sim 300 \mathrm{~mL})$ was added slowly along the walls of the funnel, to 
avoid formation of emulsion. After the separation of the two phases, the lower (aqueous phase) was discarded. The upper phase was washed 3 to 4 times with distilled water ( $200 \mathrm{~mL}$ each time) to remove residual acetone or methanol. In the last washing, the lower phase was totally discarded. The PE phase was colleted in a volumetric flask $(50 \mathrm{~mL})$, making the solution pass through a small funnel containing anhydrous sodium sulfate and a glass wool plug to hold the sodium sulfate $(\sim 15 \mathrm{~g})$ and remove residual water. Total carotenoid was determined in a UV/visible spectrophotometer Beckman, $D U \otimes 640$. The shape of the spectrum (spectral fine structure) is characteristic of the chromophore, lycopene, that is an unsaturated acyclic carotenoid, which absorbs at three wavelengths, resulting in a three-peak spectrum. To calculate total lycopene content $(\mu \mathrm{g} / \mathrm{g})$ absorption coefficiente of lycopene in PE (3450) was used (FERREIRA \& RODRIGUEZ-AMAYA, 208).

\subsection{ASCORBICACID CONTENT}

The procedures used were described by MACEDO et al. (2005), based on titration method with the reduction of 2,6-diclorobenzenoindofenol (DCFI) by ascorbic acid. The results were expressed in $\mathrm{mg}$ of ascorbic acid/100 $\mathrm{g}$ of nectar.

\subsection{DETERMINATION OF TOTAL PHENOLS}

Total phenols were measured by the Folin-Ciocalteu assay (SINGLETON \& ROSSI, 1965) using gallic acid (Sigma-Aldrich, St Louis, MO, USA) for the standard curve and results were expressed in $\mathrm{mg}$ gallic acid equivalents/L (GAE). Floating particles were removed by centrifugation and juice sample diluted 1:100 with deionized water, followed by colorimetric reading at $760 \mathrm{~nm}$ with a Beckman spectrometer.

\subsection{DETERMINATION OF RADICAL SCAVENGING ACTIVITY}

DPPH (1,1-diphenyl-2-picrylhydrazil) (Sigma) was used to evaluate free radical scavenging activity of juices using the method according to KIM et al. (2002). In the radical form, DPPH presents a maximum absorption at $517 \mathrm{~nm}$, but upon reduction by a radical scavenger, a pale-yellow non-radical form is produced. Methanolic solutions of DPPH $(100 \mathrm{~mm})$ were daily prepared using methanol $80 \%$ in water. Sample aliquots of $0.1 \mathrm{~mL}$ were added to $3.9 \mathrm{~mL}$ fresh $\mathrm{DPPH}$ methanolic solution and the mixtures were kept in the dark for 30 minutes at room temperature $\left(25^{\circ} \mathrm{C}\right)$. The absorbance was measured with a Beckman spectrometer before addition of samples and after 30 minutes in the presence of samples. A standard curve of the synthetic antioxidant Trolox (6-hydroxy-2,5,7,8-tetramethyl-chroman2-carboxylic acid) (Sigma-Aldrich) was built in concentrations of $0.08-1.28 \mathrm{mM} / \mathrm{L}$ in methanol $80 \%$. Analyses were carried out in duplicates and the results expressed in $\mathrm{mM}$ Trolox equivalent (mM TE).

\subsection{DETERMINATION OFABTS RADICALANTIOXIDANT CAPACITY}

Total antioxidant capacity is a spectrophotometric technique which measures the relative abilities of antioxidants to scavenge the ABTS. ${ }^{+}$(2,2-azinobis(3-ethylbenzothiazoline-6-sulfonate) in comparison to the antioxidant capacity of standard amounts of Trolox $®$ (6-hydroxy-2,5,7,8-tetramethylchroman-2carboxylic acid), according to the methodology described by RE et al. (1999). This improved technique involves the direct production of ABTS ${ }^{+}$chromophore through the reaction between ABTS and potassium persulfate. In the presence of antioxidants the absorbance decreases and the extent of decolorization as percentage inhibition of radical cation is determined as function of concentration and time.

\subsection{DATAANALYSIS}

The ANOVA and Tukey test were used to evaluate the obtained data. For the statistical analysis, the SAS program was used (SAS, 2003). 


\section{RESULTS AND DISCUSSION}

The spectrophotometric analysis presents an estimative of the total carotenoids in guava samples in the study (Table 1), and was based on the lycopene content, because it is the predominant carotenoid in guava, with a higher concentration compared to $\beta$-carotene (FERREIRA, 2001). Lycopene content showed values from 11.09 to $16.53 \mu \mathrm{g} / \mathrm{g}$ in the samples of guava juices and nectars, close to the value estimated by PADULA (1983) to guava juice cultivar IAC-4 (20,2 $\mu \mathrm{g} / \mathrm{g})$; and over the values obtained for two guava juice brands, A and B, commercialized in São Paulo $(9.3 \mu \mathrm{g} / \mathrm{g}$ e $2.1 \mu \mathrm{g} / \mathrm{g})$.

Samples 3, 4, 5 and 6 of guava nectars, proceeding from Southeast States of Brazil, showed higher contents of lycopene compared to guava juices 1 and 2, originated from the Northeast (Table 1). These results corresponded to the ones obtained by PADULA \& RODRIGUEZ-AMAYA (1986), who found lower levels of lycopene for guava juice proceeding from the Brazilian Northeast States, compared to the one produced in the State of São Paulo (Southeast).

\section{TABLE 1 - LYCOPENE, ASCORBIC ACID AND TOTAL PHENOLIC CONTENT OF GUAVA NECTAR AND JUICE (Psidium guajava $L$.)}

\begin{tabular}{cccc}
\hline Samples & $\begin{array}{c}\text { Lycopene } \\
(\mu \mathrm{g} / \mathrm{g})^{\star}\end{array}$ & $\begin{array}{c}\text { Ascorbic acid } \\
(\mathrm{mg} / 100 \mathrm{~g})^{\star}\end{array}$ & $\begin{array}{c}\text { Total phenolic } \\
(\mathrm{mg} \text { GAE/L })^{\star}\end{array}$ \\
\hline 1 & $11.09 \pm 0.36^{\mathrm{a}}$ & $8.6 \pm 0.1^{\mathrm{a}}$ & $410.9 \pm 2.1^{\mathrm{a}}$ \\
2 & $13.91 \pm 0.11^{\mathrm{b}}$ & $9.7 \pm 0.1^{\mathrm{a}}$ & $313.4 \pm 3.9^{\mathrm{b}}$ \\
3 & $16.19 \pm 0.11^{\mathrm{c}}$ & $17.0 \pm 0.4^{\mathrm{b}}$ & $712.1 \pm 5.8^{\mathrm{c}}$ \\
4 & $14.78 \pm 0.13^{\mathrm{b}}$ & $13.8 \pm 0.4^{\mathrm{c}}$ & $464.9 \pm 5.5^{\mathrm{d}}$ \\
5 & $13.94 \pm 0.12^{\mathrm{b}}$ & $24.6 \pm 0.4^{\mathrm{d}}$ & $846.4 \pm 2.4 \mathrm{e}$ \\
6 & $16.53 \pm 0.53^{\mathrm{c}}$ & $23.2 \pm 0.76^{\mathrm{d}}$ & $777.2 \pm 3.0^{\mathrm{f}}$ \\
\hline
\end{tabular}

*Each value is the mean \pm standard deviation of three replicate experiments. Different letters represent significant differences $(\mathrm{pd}<0.05)$ in samples. GAE = gallic acid equivalent.

The "light" samples 2 and 6 presented higher levels of lycopene compared to the traditional ones, the opposite occurred to samples 3 and 4 , where the traditional version had higher lycopene content $(16.19 \pm 0,11 \mu \mathrm{g} / \mathrm{g})$ then the "light" version $(14.75 \pm 0,13 \mu \mathrm{g} / \mathrm{g})$.

The amount of ascorbic acid was different among the samples from different brands, ranging from 8.6 to $24.6 \mathrm{mg} / 100 \mathrm{~g}$. Only one brand showed differences between traditional and "light" versions. EVANGELISTA \& VIEITES (2006) found ascorbic acid content in guava pulp ranging from 4.57 to $58.04 \mathrm{mg} / 100 \mathrm{~g}$. The ranges of ascorbic acid contents ( $\mathrm{mg} / 100 \mathrm{~g})$ were 4.8-13.2 in nectarines, 3.6-12.6 in peaches and 2.5-10.2 in plums (GIL et al., 2002). The content of vitamin C can vary according to the processing conditions, storage and type of package. Those parameters can influence in the loss of vitamin $C$ in a higher or lower extension in guava pulp (PANDEY \& SINGH,1998).

The total phenolic content was significantly different among guava samples. Sample 5 presented the highest score (846.4 $\pm 2,4 \mathrm{mg}$ GAE/L). LUXIMON-RAMMA et al. (2003) reported a total phenolic content of $126.4 \mathrm{mg}$ GAE/100 g in pink pulp guava, 142.9 in starfruit, 47.9 in pineapple, 56.0 in mango, 57.6 in papaya and $28.8 \mathrm{mg}$ GAE/100 $\mathrm{g}$ in litchi.

TEAC of guava juices and nectars obtained by DPPH and ABTS assays is shown in Figure 1. There are a number of factors that influence the effectiveness of antioxidants in complex heterogeneous foods and biological systems and in multiphase models. These include the lipid/ aqueous phase partitioning properties of the antioxidants, the oxidation conditions and the physical state of the oxidizable substrate (FRANKEL \& MEYER, 2000). The influence of all relevant 
parameters can not be evaluated using only one assay protocol; therefore two systems were chosen to evaluate the antioxidant capacity of guava nectar and juice. DPPH and ABTS.+ measure the radical scavenging activity in organic system.

\section{FIGURA 1 - TEAC OF 6 SAMPLES OF GUAVA JUICES AND NECTARS BY ABTS AND DPPH - SCAVENGING ASSAY}

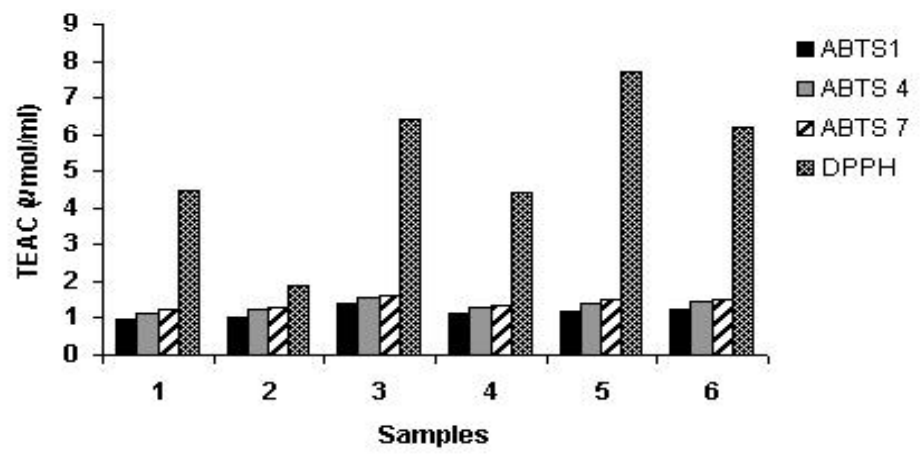

The TEAC values obtained through the cation ABTS.+ and radical DPPH are shown in Table 2. The samples 3,5 and 6 presented higher scavenging activity compared to the others. In vitro antioxidant capacities of the different guava nectars and juices tested varied considerably. Total antioxidant capacity measured from DPPH was found to vary four fold from that at the lowest value. Sample 5 with $7.7 \mu \mathrm{mol} / \mathrm{mL}$ is classified as containing high antioxidant capacity. The antioxidant defense system of the body is composed of a mixture of antioxidants. Fruits are good sources of antioxidants that may be more effective and economical than supplements in protecting the body against oxidative damage under different conditions. Fruit antioxidants, which include ascorbic acid, tocopherol, carotenoids and phenolics, vary greatly in their contents and profile among various fruits. As a result, the antioxidant capacity of one fruit differs considerably from another (LEONG \& SHUI, 2002).

TABLE 2 - IN VITRO ANTIOXIDANT CAPACITY OF GUAVA NECTAR AND JUICE (Psidium guajava L.)

\begin{tabular}{ccccc}
\hline Samples & \multicolumn{3}{c}{$\mathrm{ABTS}^{+}(\mu \mathrm{mol} / \mathrm{mL})^{\star}(\mathrm{a})$} & $\mathrm{DPPH}(\mu \mathrm{mol} / \mathrm{mL})^{\star}(\mathrm{b})$ \\
\hline 1 & 1 minuto $^{\mathrm{4}}$ & 4 minutos & 7 minutos & \\
\hline 2 & $0.97 \pm 0.05^{\mathrm{a}}$ & $1.11 \pm 0.06^{\mathrm{a}}$ & $1.23 \pm 0.05^{\mathrm{a}}$ & $4.5 \pm 0.14^{\mathrm{a}}$ \\
3 & $1.05 \pm 0.03^{\mathrm{ad}}$ & $1.23 \pm 0.07^{\mathrm{a}}$ & $1.31 \pm 0.07^{\mathrm{a}}$ & $1.9 \pm 0.09^{\mathrm{b}}$ \\
4 & $1.15 \pm 0.04^{\mathrm{b}}$ & $1.58 \pm 0.04^{\mathrm{b}}$ & $1.64 \pm 0.01^{\mathrm{b}}$ & $6.4 \pm 0.26^{\mathrm{c}}$ \\
5 & $1.18 \pm 0.07^{\mathrm{cd}}$ & $1.27 \pm 0.07^{\mathrm{ac}}$ & $1.34 \pm 0.05^{\mathrm{ac}}$ & $4.4 \pm 0.17^{\mathrm{d}}$ \\
6 & $1.26 \pm 0.01^{\mathrm{ad}}$ & $1.45 \pm 0.03^{\mathrm{bc}}$ & $1.50 \pm 0.03^{\mathrm{bc}}$ & $7.7 \pm 0.4^{\mathrm{e}}$ \\
\hline
\end{tabular}

* Each value is the mean \pm standard deviation of three replicate experiments. Different letters indicate significantly different values $(\mathrm{pd}<0.05)$. Antioxidant capacity was measured through the (a) cation ABTS and expressed in $\mu$ mol of Trolox equivalent, and through the (b) radical. DPPH expressed in $\mu \mathrm{mol}$ of Trolox equivalent. 
The ABTS scavenging capacity of guava juices and nectars at different reaction times is presented in Table 2. Samples 1 and 2 had the lowest capacity in quenching ABTS.+ ${ }^{+}$the three reaction times. Relatively high ABTS.+ scavenging capacity at the examined reaction times was observed in sample 3. All the samples showed antioxidant capacity up to seven minutes of reaction. PELLEGRINI et al. (2003) found TEAC values of $1.83 \mathrm{mmol}$ Trolox / $\mathrm{L}$ for apple juice, $1.50 \mathrm{mmol}$ Trolox /L for pineapple juice, $3.02 \mathrm{mmol}$ Trolox /L for orange juice. THAIPONG et al. (2006) evaluated four different extracts of guava tissue and found an average of $31.1 \mu \mathrm{mol}$ Trolox/g.

WANG et al.(1998) found that some compounds, which have ABTS ${ }^{+}$scavenging activity may not show DPPH scavenging activity. In this study ascorbic acid and phenolics are the major contributors to antioxidant activity in guava nectar and juice. The evaluated parameters showed that guava nectar and juice can be a good source of both natural antioxidants and synthetic antioxidant.

Table 3 shows correlation among the different parameters. Although both methods, ABTS ${ }^{+}$and $\mathrm{DPPH}$, used in this study are based on the same property, i. e., the capacity for radical scavenging, they rank the guava products differently. It is probable that the observed differences are due to the solubility of each antioxidant component. Some are of a hydrophilic nature (e.g. ascorbic acid) and others are clearly lipophilic (e.g. lycopene). DPPH is more indicated for hydrophilic compounds and ABTS ${ }^{+}$can be used to estimate hydrophilic and lipophilic antioxidant activity, depending on the reaction medium used (ARNAO, CANO \& ACOSTA, 2001).

TABLE 3 - PEARSON'S CORRELATION COEFFICIENTS OF ANTIOXIDANT ACTIVITIES, ASCORBIC ACID, TOTAL PHENOLICS, AND TOTAL CAROTENOIDS CONTENT

\begin{tabular}{cccccccc}
\hline Trait $^{\mathrm{a}}$ & TPH & AA & LYC & DPPH & \multicolumn{3}{c}{ ABTS } \\
\cline { 6 - 8 } & & & & & 1 minute & 4 minutes 7 minutes \\
\hline TPH & 1.00 & $0.95^{\star}$ & 0.54 & $0.95^{\star}$ & 0.70 & 0.79 & $0.84^{\star}$ \\
AA & $0.95^{\star}$ & 1.00 & 0.60 & $0.84^{\star}$ & 0.61 & 0.72 & 0.76 \\
LYC & 0.54 & 0.60 & 1.00 & 0.33 & $0.87^{\star}$ & $0.86^{\star}$ & 0.81 \\
DPPH & $0.95^{\star}$ & $0.84^{\star}$ & 0.33 & 1.00 & 0.60 & 0.66 & 0.72 \\
ABTS1 & 0.70 & 0.61 & $0.87^{\star}$ & 0.60 & 1.00 & $0.98^{\star}$ & $0.96^{\star}$ \\
ABTS4 & 0.79 & 0.72 & $0.86^{\star}$ & 0.66 & $0.98^{\star}$ & 1.00 & $0.99^{\star}$ \\
ABTS7 & $0.84^{\star}$ & 0.76 & 0.81 & 0.72 & $0.96^{\star}$ & $0.99^{\star}$ & 1.00 \\
\hline
\end{tabular}

a $\mathrm{TPH}=$ total phenolics, $\mathrm{AA}=$ ascorbic acid, $\mathrm{LYC}=$ lycopene, $\mathrm{ABTS}=$ antioxidant activity measured in methanol extract based on ABTS assay in three times (1,4,7 minutes), DPPH = antioxidant activity measured in methanol extract based on DPPH assay.

* significant at $p<0.05$

\section{CONCLUSION}

The ABTS and DPPH, assays gave comparable results for in vitro antioxidant activity measured in methanol extracts of guava juices and nectars. DPPH showed high correlation with both ascorbic acid and total phenolics, while ABTS ${ }^{+}$had higher correlation with lycopene. Ascorbic acid and phenolics are the major contributors to antioxidant activity in guava juice and nectar. In general, the antioxidant activity of guava products depends on several different factors, including the analytical method, plant variety and geographic origin. The study showed that both ABTS and DPPH methods can be used to study in vitro antioxidant capacities in guava products.

\section{RESUMO}

\section{CAPACIDADE ANTIOXIDANTE, COMPOSTOS FENÓLICOS, ÁCIDO ASCÓRBICO E CONTEÚDO DE LICOPENO DE NÉCTARES E SUCOS DE GOIABA (Psidium guajava $L$.)}

O objetivo deste trabalho foi determinar a capacidade antioxidante in vitro de três diferentes marcas de néctares e sucos de goiaba, através de métodos de sequestro de radicais livres, 2,2'-azino-bis 
(3-etilbenzitiazolina-6-sulfonato) $\left(\right.$ ABTS $\left.^{+}\right)$e 1,1-difenil-2-picrilhidrazila (DPPH) e sua correlação com o conteúdo total de polifenóis, total de licopeno e ácido ascórbico. As marcas revelaram diferença estatística ( $\mathrm{p} \leq 0.05$ ) na capacidade antioxidante, variando de 1,9 a $7,7 \mathrm{molTE} / \mathrm{mL}$. O resultado da capacidade antioxidante apresentou correlação positiva para o teor de ácido ascórbico e compostos polifenólicos, sendo relativamente baixo para o licopeno. Diferentes processos podem influenciar o conteúdo desses compostos em néctares sucos de goiaba, assim como interferir na sua capacidade antioxidante. O controle do processo de produção é importante para agregar valor aos produtos de goiaba e atender a nova tendência do mercado.

PALAVRAS-CHAVE: ANTIOXIDANTE; GOIABA; SUCO; Psidium guajava L.

\section{REFERENCES}

1 ARNAO, M.B.; CANO, A.; ACOSTA, M. The hydrophilic and lipophilic contribution to total antioxidant activity. Food Chemistry, v.73, p. 239-244, 2001.

2 EVANGELISTA, R.M; VIEITES, R.L. Avaliação da qualidade de polpa de goiaba congelada, comercializada na cidade de São Paulo. Segurança Alimentos e Nutrição, v.13, n.2, p.76-81, 2006.

3 FERREIRA, J.E.M. Cinética e fatores que influenciam na degradação de carotenóides em sistemas modelos e alimentos. 2001. 85 f. Dissertação (Mestrado em Ciência de Alimentos), Faculdade de Engenharia de Alimentos, Universidade Estadual de Campinas. Campinas, 2001.

4 FERREIRA, J.E.M.; RODRIGUEZ-AMAYA, D.B. Degradation of lycopene and $\beta$-carotene in model systems and in lyophilized guava during ambient storage: kinetics, structure and matrix effects. Journal of Food Science, v. 73, p. 589-594, 2008.

5 FORGET, F. L.; GAUILLARD, F.; RIGAL, D. Changes in the carotenoid content of apricot (Prunus armeniaca, var. Bergeron) during enzymatic browning: â-carotene inhibition of chlorogenic acid degradation. Journal of the Science of Food and Agriculture, v.80, p.763-768, 2000.

6 FRANKEL, E.N.; MEYER, A.S. The problems of using one-dimensional methods to evaluate multifunctional food and biological antioxidants. Journal of the Science of Food and Agriculture, v.80, p.1925-1941, 2000.

7 GIL, M.I.; TOMAS-BARBERAN, F.A.; HESS-PIERCE, B.; KADER, A. Antioxidant capacities, phenolic compounds, carotenoids, and vitamin $C$ contents of nectarine, peach and plum cultivars from California. Journal of Agricultural and Food Chemistry, v. 50, p. 4976-4982, 2002.

8 KIM, D.O; LEE, K.W.; LEE, H.J.; LEE, C.Y. Vitamin C equivalent antioxidant capacity (VCEAC) of phenolic phytochemicals. Journal of Agricultural and Food Chemistry, v. 50, n.13 p.3713?-3717, 2002.

9 LEONG, L.P.; SHUI, G. An investigation of antioxidant capacity of fruits in Singapore markets. Food Chemistry, v. 76, p. 69-75, 2002.

10 LUXIMON-RAMMA, A.; BAHORUNT, T.; CROZIER, A. Antioxidant actions and phenolic and vitamin C contents of common Mauritian exotic fruits. Journal of the Science of Food and Agriculture, v. 83, n.5, p. 496-502, 2003.

11 MACEDO, G.A.; PASTORE, G.M; SATO, H.H; PARK, Y.K. Bioquímica experimental de alimentos. São Paulo: Varela, 2005. $187 \mathrm{p}$.

12 MERCADANTE, A.Z. Chromatographic separation of carotenoids. Archivos Latinoamericanos de Nutricion, v. 49, p. 52-57, 1999.

13 PADULA, M. Goiaba (Psidium guajava L.) cultivar IAC-4: carotenóides e outras propriedades, mudanças durante processamento e estocagem. Campinas, 1983. 106 p. Dissertação (Mestrado em Ciência de Alimentos), Faculdade de Engenharia de Alimentos, Universidade Estadual de Campinas.

14 PADULA, M.; RODRIGUEZ-AMAYA, D.B. Characterization of the carotenoids and assessment of the vitamin A value of Brazilian Guavas (Psidium guajava L.). Food Chemistry, v. 20, n. 1, p. 11-19, 1986.

15 PANDEY, A.K.; SINGH, I.S. Physico-chemical studies on utilization of guava cultivars. Progressive Horticulture, v.30, n.1, p.73-75, 1998.

16 PELLEGRINI, N.; SERAFINI, M.; COLOMBI, B.; DEL RIO, D.; SALVATORE, S.; BIANCHI, M.; BRIGHENTI, F. Total antioxidant capacity of plant foods, beverages and oils consumed in Italy by three different in vitro assays. Journal of Nutrition, v.133, p. 2812-2819, 2003.

17 PORCU, O. M. Fatores que influenciam na composição de carotenóides em goiaba, acerola, pitanga e seus produtos processados. 2004. 135 f. Dissertação (Mestrado em Ciência de Alimentos), Faculdade de Engenharia de Alimentos, Universidade Estadual de Campinas. Campinas, 2004. 
18 RE, R.; PELLEGRINI, N.; PROTEGGENTE, A.; PANNALA, A.; YANG, M.; RICE-EVANS, C.A. Antioxidant activity applying an improved ABTS radical cation decolorization assay. Free Radiology Biology \& Medicine, v. 26, p. 1231-1237, 1999.

19 RODRIGUEZ-AMAYA, D.B.; KIMURA, M. HarvestPlus handbook for carotenoid analysis. Washington D.C.: HarvestPlus, 2004. (Technical Monograph Series, 2)

20 RODRIGUEZ-AMAYA, D.B. A guide to carotenoids anaylsis. Washington D.C.: International Life Science Institute Press, 1999.

21 SAS Institute. SAS User's Guide: statistic. Version 9.1.3. 2003.

22 SINGLETON, V.L.; ROSSI, J.A. Colorimetry or total phenolic with phosphomolybdic phosphotungstic acid reagents. American Journal of Enology and Viticulture, v.16, n.13, p.144 -158, 1965.

23 THAIPONG, K.; BOONPRAKOB, U.; CROSBY K.; CISNEROS-ZEVALLOS, L; BYRNE, L. Comparison of ABTS, DPPH, FRAP, and ORAC assays for estimating antioxidant activity from guava fruit extracts. Food Composition and Analysis, v. 19, p. 669-675, 2006.

24 WANG, M.F.; LI J.; RANGARAJAN, M.; SHAO, Y.; LAVOIE, E.J.; HUANG, T.; HO, C. Antioxidative phenolic compounds from Sage (Salvia officinalis). Journal of Agricultural and Food Chemistry, v.46, p. 4869-4873, 1998.

\section{ACKNOWLEDGMENTS}

We are grateful to CAPES and CNPq for financial support. 